\title{
THE RIGHT TO INTERNAL SELF-DETERMINATION IN PEACEBUILDING PROCESSES: A REINTERPRETATION OF THE CONCEPT OF LOCAL OWNERSHIP FROM A LEGAL PERSPECTIVE ${ }^{1}$
}

\author{
EBRU DEMIR ${ }^{2}$
}

\begin{abstract}
The right to internal self-determination offers a legal 'checklist' for the UN to provide both legitimacy and sustainability to peacebuilding processes. The right both clarifies the actors of postconflict reconstruction and also concretises to what extent these actors should be incorporated into peacebuilding processes. Although the concept of local ownership has become an often-cited concept in peacebuilding literature, the legal ground of the concept (i.e. the right to internal self-determination) has been disregarded. This paper aims to reveal the legal aspect of the concept of local ownership and thus, attaches the right to internal self-determination with local ownership.
\end{abstract}

Keywords: The Right to Internal Self-Determination; Economic Self-Determination; Political SelfDetermination; Local Ownership; Peacebuilding.

Summary: I. InTRoduction; II. A Right NeEDS TO BE EXPLORED: INTERnAL SELF-DeterminAtion; II.1. The Legal Foundations of Internal Self-Determination; II.2. The Right to Internal SelfDetermination: Definition, Scope and Methods; II.3. The Relationship between Internal and External Self-Determination Rights; III. InTERnAl SELF-DETERMinATION IN A PEACEBUILDing CONTEXT: LOCAL OWNERSHIP?; III.1. The Scope of Peacebuilding Operations and its Growing Relationship with the Concept of Internal Self-Determination; III.2. Local Ownership as a Legal Obligation for the UN: The Application of Internal Self-Determination to the Peacebuilding Context; III.3. Local Ownership as a Hard Task for the UN: the Challenges of Application with relation to the Identification of Local Actors; IV. The CASE OF THE CONGO: EXCLUSION OF LOCAL OWNERSHIP FROM THE PEACEBUILDING PROCESS; IV.1. A story of failure: Where is Local in the Congo Peace Process?; IV.2. Ignorance of Local Actors as a Violation of Internal Self-Determination: Is this a UN 'Peacebuilding Culture'? ; V. CONCLUSION.

\section{INTRODUCTION}

In the wake of the Cold War, as a result of a substantial increase in the mandates of peace operations, the form of peace operations has changed and the intrusiveness of the UN has increased. However, despite the increasing mandates, peace operations are falling behind creating long-lasting peace. In response to this profound dilemma, the United Nations (the UN) started to promote a concept which can be roughly defined as enabling local actors to make key decisions in peace processes: local ownership.

\footnotetext{
${ }^{1}$ I would like to thank Hakan Kolcak for taking time to review the draft versions of this article.

${ }^{2}$ PhD Candidate in Law, University of Sussex Law School, United Kingdom (E.Demir@sussex.ac.uk).
} 
The concept has attracted great interest in the peacebuilding literature. The involvement of local actors in peace processes has been supported to different extents by various scholars. However, with relation to the source of the concept, there has been little or no research carried out. This article argues that the source of the concept should be the right to internal self-determination for the population at stake. It is asserted that internal self-determination offers a legal ground for terminating the ambiguity of local ownership to a large extent. As a whole, I aim to clarify the relationship between peacebuilding and internal self-determination, which has always been clouded by an overestimation of the relationship between external self-determination and peace processes.

Section 2 provides a theoretical framework for the study. The right to internal self-determination is scrutinised here in detail. The legal foundations of the concept are marked. The scope and holders of the right are examined under a human rights approach. Moreover, the section aims to clarify two different aspects of the right: the political and the economic aspects. By analysing and concretising the right, it is intended to make it easier to prepare a framework for local ownership on the grounds of the right to internal self-determination.

Section 3 provides a reinterpretation of the concept of local ownership as a legal obligation. The inconclusive debate about the identification of local actors is raised. Local actors and the extent of their involvement are determined from the perspective of the right to internal self-determination. Despite the challenges to local ownership for a post-conflict country, it is claimed that the sustainability and legitimacy of a peacebuilding process depends on the involvement of the local actors.

Section 4 provides an opportunity to discuss the significance of the reinterpretation of local ownership as a legal obligation for the sustainability and legitimacy of a peace process through a case study: the Democratic Republic of the Congo (the Congo). In this section, it is illustrated that since the concept of local ownership is recognised only as a guideline on the part of the UN, it shoulders no responsibility in practice; and the UN applies the concept inconsistently, as happened in the Congo. The section concludes that reinterpretation of local ownership as a legal obligation might create a consistent application of the concept.

\section{A Right NEEDS TO BE EXPLORED: INTERNAL SELF-DETERMINATION}

\section{II.1. The Legal Foundations of Internal Self-Determination}

The codification of the right to self-determination in the UN Charter has a particular importance as it illustrates an international consensus over the recognition of the right (UN Charter, articles 1(2) and 55). ${ }^{3}$ However, the heyday of the principle was

\footnotetext{
${ }^{3}$ In article 1(2) UN Charter states that one of its main goals is to 'develop friendly relations among nations based on respect for the principle of equal rights and self-determination of peoples (...)'. Similarly, the Charter elaborates the right at stake more in article 55 and links 'peaceful and friendly relations among nations' with self-determination of peoples.
} 
the 1950-1971 period (Alston 2001, p. 262), when decolonization and the rapid development of international human rights law rendered the right to self-determination a globally-acknowledged principle, ultimately stimulating the UN to recognise the right in its General Assembly Resolutions. These developments are analysed below respectively. The jurisprudence of the International Court of Justice is not assessed as a contribution since it has never directly confronted with the principle of selfdetermination beyond the colonial context (Crawford 2001, p. 36).

Both of the International Human Rights Covenants - the International Covenant on Economic, Social and Cultural Rights (the ICESCR) and the International Covenant on Civil and Political Rights (the ICCPR) - recognize the right to self-determination in their common Article 1 for all peoples. ${ }^{4}$ It can be claimed that these two covenants were the first substantial steps to providing a context to the right to self-determination beyond the colonial framework. This is because neither of these Covenants restricted the scope or subjects of the right to colonial peoples (Castellino 2000, p. 32). Thus, the right of self-determination has gained a post-colonial scope, in addition to the colonial one.

Furthermore, international human rights bodies also contributed to the development of the scope of the right. The Human Rights Committee (the HRC) made it clear that self-determination has some ramifications in the ICCPR. By this, the HRC added an ongoing aspect to the principle. In its General Comment, the HRC connected Article 1 with Article 25 which provides, inter alia, the right to take part in public affairs and to have access to the public service of one's own country. The HRC held that these mentioned rights are closely related to the right to self-determination (UN HRC GC 25, paras 1 and 2). As David Raic maintained, the collective right to internal selfdetermination in Article 1 and the political rights in Article 25 have been "inextricably bound up" with each other by the HRC (Raic 2002, p. 274).

This argument begs a question: Can holders of this right bring a claim to the HRC under Article 1 with relation to the violation of any other rights? According to Antonio Cassese, this question should be answered in the affirmative. Cassese held that when the economic rights of a group are violated, an individual in this group can complain about the violation of, for instance, Article 25 and at the same time Article 1 (Cassese 1995, p. 145). However, in practice, the HRC rejected all individual communications for self-determination. One of these communications was the Kitok case. In this case, the HRC found the communication inadmissible since an individual cannot claim to be a victim of a violation of the right to self-determination (Ivan Kitok $v$ Sweden para. 6.3). On many occasions the HRC did not find admissible any communication for self-determination. That is why it is hard to mention any contribution of the HRC to the development of the right to internal self-determination beyond its General Comment 25.

\footnotetext{
${ }^{4}$ Article 1 of ICCPR and also Article 1 of ICESR provide that all peoples have the right to selfdetermination.
} 
Unlike the HRC, the African Commission on Human and Peoples' Rights (the ACHPR) extended its enforcement mechanisms in a way that includes all categories of rights. The African Charter on Human and Peoples’ Rights (the Banjul Charter) allows communications both from states under Article 47 and from individuals under Article 55 for bringing a claim against the violations of any rights in the Banjul Charter. ${ }^{5}$ This is a very crucial step which enables individuals to allege violations of their internal selfdetermination, as happened in the Katangese Peoples' Congress v. Zaire (the Katangese) case. In this case, an individual, the President of the Katangese Peoples' Congress, alleged the violation of the self-determination of the people of Katanga under Article 20(1) of the Banjul Charter. The ACHPR, in Katangese in which the President of the Katangese Peoples' Congress alleged the violation of the self-determination of the people of Katanga under Article 20(1) Banjul Charter, recognised the post-colonial context of self-determination for the first time in its jurisprudence by ruling that all peoples have a right to self-determination (Mhango 2007, p. 14). Moreover, the ACHPR illustrated the ways in which peoples are able to exercise their right to internal selfdetermination as follows: "self-government, local government, federalism, confederalism, unitarism or any other form of relations that accord with the wishes of the people" (Katangese Peoples' Congress $v$ Zaire para. 4). On the basis of this wording, it seems fair to hold that the ACHPR clearly distinguishes the colonial and non-colonial aspects of the right to self-determination. Equally important, here the ACHPR attaches the violation of self-determination to the infringement of other human rights. In other words, if there is evidence of gross violations of any rights in the Banjul Charter, then there is also a violation of the right to internal self-determination. Thus, this case shows that the ACHPR would find reasonable grounds for the violation of internal self-determination if the human rights of the Katangese were violated. On such an occasion, the people at stake could be granted self-government (or any other way mentioned in the case) to enjoy their right to internal self-determination.

However, the decision was not without problems. Although the ACHPR granted self-determination to all peoples, it did not define the meaning of 'peoples'. According to one scholar, the reason for this is the political sensitivity of the issue (Thio 2002, p. 466). In other words, the possible increase in the number of claims for internal selfdetermination, and even external self-determination, forced the ACHPR to take a 'conservative approach' on this issue (ibid). Besides, it can be argued that the lack of a definition of 'peoples' can cause arbitrary decisions when deciding which group can be considered a people and which cannot. Nevertheless, the contribution of the ACHPR cannot be denied. This human rights body enables individuals to bring claims on behalf of groups for the violation of the right to internal self-determination. Thus, the right at stake becomes justiciable in front of the ACHPR.

Another crucial contribution to the development of internal self-determination was made by the GA. The first step was the 1960 Declaration on the Granting of Independence to Colonial Countries and Peoples. In this declaration, all peoples were

\footnotetext{
${ }^{5}$ Article 47 of the Banjul Charter enables a state to bring claim against another state party in case of infringement of a human right provided in the Charter. In article 55, 'communications other than those of States parties to the present charter' enables individual communications.
} 
granted self-determination. Moreover, in regard to this right they could freely determine "their political status and freely pursue their economic, social and cultural development" (UN GA Declaration 1960, para. 2). The significance of this declaration is two-fold. First, the right to self-determination goes beyond the colonial context by means of the term all peoples. Second, the declaration clarifies the content of the right by attaching it to determination of political status and to the right to pursue economic, social and cultural rights. Similarly, the 1970 Declaration on Friendly Relations adopted almost the same wording about the right to self-determination (UN GA Declaration 1970). It was unanimously adopted and paved the way for the development of self-determination beyond the colonial context (Alston 2001, p. 260). According to the wordings of both declarations, it seems that self-determination can be fulfilled by the enjoyment of economic, social and cultural human rights. Although this is not the whole idea about internal self-determination, this framework is completely in compliance with the HRC's General Comment 25 discussed above.

The development of the concept of internal self-determination does not end with these declarations. However, the aim of this section is not to give a comprehensive historical background to the principle of self-determination. Such works have been done before (see Thürer and Burri 2010). Instead, it is emphasized here that the development of internal self-determination goes back a long way. What is crucial for this section is to see that the pioneer sources of internal self-determination also outlined the conceptual framework of the concept. They explored the internal aspect of the right to selfdetermination beyond the colonial context and linked it with the enjoyment of human rights.

\section{Methods}

II.2. The Right to Internal Self-Determination: Definition, Scope and

As discussed in the first section, the right to self-determination applies to all peoples, so not only to colonial peoples as holders of the right. Thus, the terminology signifies a universal and ongoing character of this right (Raic 2002, p. 228). While the external aspect of the right to self-determination is mainly associated with decolonization, internal self-determination "directly relates with the spirit and application of international human rights law" in an ongoing process (Germanakou 2007, p. 2).

First, it should be emphasized that both internal and external self-determination are still applicable. However, internal self-determination is the first resort. In other words, all peoples might have both rights, but the application should have an order. Under the principles of territorial integrity and sovereignty, the application of external self-determination becomes the last resort. It seems clear that the UN adopts this approach. That is to say, external self-determination seems to be a last resort in the documents of the UN. For instance, the 1970 Friendly Relations Declaration held that the wording of the Declaration cannot be interpreted "as authorizing or encouraging any action which would dismember or impair, totally or in part (...)” (UN GA Declaration 
1970, Annex). It can therefore be inferred that the UN does not promote the external layer of the right to self-determination. On the contrary, the UN strongly promotes the internal layer since it is in compliance with the principle of sovereign equality and territorial integrity. ${ }^{6}$

Internal self-determination has two main aspects ${ }^{7}$ : political and economic. These dimensions are analysed next, and then the holders of the rights are scrutinised.

The political aspect of internal self-determination: The 1970 Friendly Relations Declaration laid the groundwork for the scope of the political aspect of the right to internal self-determination. It encouraged states to have a government which represents all the peoples in the territory at stake "without distinction as to race, creed or colour" (ibid). Thus, each state has the responsibility within its borders to have a representative government mechanism. This dimension of internal self-determination, as the HRC approved above, is much related to the entitlement to political participation. In other words, all peoples can choose their own political status and the form of their government under the right to internal self-determination (McCorquodale 1994, p. 864). Under this right, they have a right to govern themselves, take part in public affairs and participate in elections and referenda and so on (Rosas 1993, p. 249).

The application field of internal self-determination is intra-state relations (Raic 2002, p. 237). The relationship of the state and government with the peoples of the territory at stake is the main concern of the concept. The concept requires a transparent and accessible government which prioritizes all peoples equally without distinction as to race, creed or colour (Germanakou 2007, p. 19). Therefore, all peoples belonging to that territory can have the opportunity to take part in public affairs.

Without any distinction, all peoples should enjoy their economic, social and cultural human rights. It can be asserted that internal self-determination actually requires a legitimate state and government which is participative, representative and pluralist. In this sense, the theories of democracy and internal self-determination have close relations. Although the connections between democracy and the right to internal self-determination is beyond the scope of this paper, it is fair to say that enjoyment of economic, social and cultural rights is also main principle of democracy. However, the question of whom will enjoy these rights (individuals or groups) seems like the major difference between democracy and the right to internal self-determination. (For more, see Fan 2008; Wolff 2014) For now, it should be affirmed that the political aspect of the right requires states and their governments to enable all peoples to enjoy 'a right to have a say’ in the political decision-making process (Raic 2002, p. 237).

\footnotetext{
${ }^{6}$ Sovereign equality (UN Charter article 2(1)) and territorial integrity (UN Charter article 2(4)) are among the main principles of the UN.

${ }^{7}$ There are growing discussions regarding all aspects of the right to internal self-determination, such as social and cultural aspects. For instance, cultural dimension of internal self-determination has been reminded by numerous fellow individuals in recent years, particularly related to minorities (LGBTIs, the Roma, immigrants in Western Europe, to name just a few) (See Green 1995).
} 
The economic aspect of internal self-determination: Another aspect of internal self-determination can be termed 'economic self-determination'. It is a very crucial right since its enjoyment enables the beneficiaries to enjoy their other human rights. To put it another way, the realization of economic self-determination paves the way for enjoying other human rights in both of the international human rights covenants, such as the rights to health, housing and education (Farmer 2006, p. 420).

Consideration of this aspect of the right has been more neglected in comparison with the political aspect, although it also has its foundations in both of the international human rights covenants (common Article 1(2)). According to the same wording in both of the covenants, all peoples have a right to dispose their natural resources freely (ICCPR art 1(2)). This can be adapted to a context which is beyond the colonial period under a human rights approach. In other words, a human rights approach enables us to expand the scope of the right beyond the colonial context. Thus, it can be concluded that all peoples belonging to a territory can claim control over the natural resources of that territory (Farmer 2006, p. 419).

The term 'freely dispose' has two meanings. According to Alice Farmer, first, it means that a representative body should distribute natural resources transparently (ibid p. 430). Here, it is clear that the theory of democracy again overlaps with economic internal self-determination. The second meaning of the phrase requires that natural resources must be used for the peoples' own ends (ibid). In other words, the resources must be distributed equally for the benefit of the peoples.

Despite its importance, economic self-determination has always been underestimated in the literature. However, the ACHPR made a great contribution to the development of economic self-determination in the Social and Economic Rights Action Centre (SERAC) and another $v$ Nigeria (the SERAC) case. Although this case is one of the milestones of environmental law, it is also very crucial for clarifying the duties of states with relation to the economic aspect of internal self-determination. In SERAC, the communication alleged that in Ogoniland an oil consortium had exploited the oil reserves with the permission of the government (para. 2). This created contamination of the environment of Ogoniland. The Ogoni people, who is one of the peoples in Nigeria, were severely affected by this situation. The issue with regard to internal selfdetermination was that the Ogoni people had not been allowed to be involved in the decision-making process (ibid para 4). Thus, the communication was brought on behalf of the Ogoni people under, inter alia, Article 21 of the Banjul Charter which grants economic self-determination.

The ACHPR found a violation of, inter alia, Article $21^{8}$ (ibid para. 70). More importantly, it analysed the nature of the right to economic self-determination and identified three dimensions of the right. The first dimension was that the ACHPR held that the government did not respect the decisions of the Ogoni people by excluding

\footnotetext{
${ }^{8}$ Article 21 of the Banjul Charter addresses the right to economic self-determination of all peoples by providing the right with an ongoing aspect without needing to secessionary external self-determination.
} 
them from the decision-making process (ibid para 55). This expression may have two meanings. First, that the decision-making process should be inclusive. The beneficiaries of the natural resources, in this case the Ogoni people, should have been allowed to participate in this process and their decision should have been respected. Second, a state and its actors should refrain from preventing the peoples' enjoyment of their economic self-determination.

The second dimension is that the ACHPR clearly pointed out that states have to protect their citizens through legislative and effective enforcement and by protecting them from damage caused by private actors (ibid para. 57). Thus, states also have to protect their citizens from the harmful acts of third parties. The final dimension of the right is that the government did not facilitate the Ogoni people to enjoy their right at stake; conversely, it facilitated the destruction of the Ogoniland (ibid para. 58). Thus, the ACHPR recognised that states should take positive steps that might enable peoples to have a greater enjoyment of the right to economic self-determination. The SERAC concretized the meaning and scope of the right to economic self-determination and it illustrated the fact that the right has different dimensions in itself. Thus, a state cannot release itself from the obligation by just preventing its actors from violating the right concerned. It also has to prevent third parties' interference, and moreover it has to facilitate the enjoyment of the right by different measures, such as legislative, administrative or judicial (remedial) measures.

All in all, both the political and economic aspects of internal self-determination can be concisely summarized by the words of Jan Klabbers: the right to be taken seriously (Klabbers 2006, p. 202). From both aspects, all groups should have a right to contribute to shaping their own political and economic future. For this to happen, states should take the decisions of these groups seriously and grant them certain procedural rights, such as freedom of expression, freedom of assembly and freedom from discrimination (ibid p. 205).

It should be emphasised here that when these rights are enjoyed by individuals, this does not mean that internal self-determination is necessarily respected. The main reason for this is that the identity of a group can be different from the sum of the identities of its individual members (Raic 2002, p. 239). Thus, the interests of a group will be different from the sum of the interests of each individual within it. Breaking groups into their various components would undermine the group identity (Klabbers 2006, p. 205). Thus, the subjects of the right to internal self-determination whose rights should be taken seriously are groups.

The holders of the right at stake: The holders of the right have been decided as "all peoples" in both covenants (ICCPR article 1 and ICESR article 1). It is clear that the right has beneficiaries beyond the colonial societies. However, there is still an ambiguity about how these peoples can be identified. In other words, what is the meaning and scope of the term 'peoples' in this context? 
In the jurisprudence of the HRC, the issue of the subjects of internal selfdetermination is a problem. The HRC seems far from clarifying the subjects of internal self-determination. This can be clearly seen in the Mikmaq case. In this case, the HRC rejected the violation of self-determination claim brought by an individual on behalf of the Mikmaq tribal society (Mikmaq Tribal Society $v$ Canada). However, the individual opinion in this case has a particular importance. An HRC member, Mr Roger Errera asked two crucial questions: If the Optional Protocol of the ICCPR allows all individuals to bring a claim in the case of a violation of all the rights set forth in the ICCPR, why cannot an individual claim a violation of the right to self-determination? (ibid). And, equally important, is the Mikmaq tribal society a 'people' within the meaning of the ICCPR? (ibid) It can be claimed that the main concern of the member who asked these questions was to interrogate the beneficiaries of the right to selfdetermination. The current jurisprudence of the HRC is not helpful for finding the holders of the right to internal self-determination. On the contrary, it is confusing since it rejects all claims brought by individuals on behalf of groups. By doing this, the HRC is making this right non-justiciable under international human rights law.

In line with the purpose of this paper, when scrutinising the holders of the right at stake, a human rights approach is applied. And to avoid the ambiguity of using the term 'peoples' since its singular and plural forms are confusing, 'groups' will be advocated as the beneficiaries of the right to internal self-determination here. Under the human rights approach, whereas all groups in a territory at stake have this right, the implementation of this right can only be realized by the groups who are denied their economic, social and cultural rights as a result of their "race, creed or colour" under the 1970 Friendly Relations Declaration. Although the wording of this declaration seems only to prohibit distinctions on the grounds of race, creed or colour, race should be interpreted within the context of the International Convention on the Elimination of All Forms of Racial Discrimination (the Convention). The first article of the Convention defines racial discrimination as "any distinction, exclusion, restriction or preference based on race, colour, descent, or national or ethnic origin (...)” (ICERD 1965, article 1). Clearly, the Convention interprets the scope of race broadly. Similarly, under the human rights approach, the subjects of internal self-determination should be expanded as more recent regulations conceive the holders of the right more broadly.

The development of the theory of self-determination is still continuing. In this process, the 1993 Vienna Declaration and Programme of Action (the Vienna Declaration) was a milestone. The Vienna Declaration confirmed self-determination as a right for all groups. Moreover, it took the wordings of the previous Declarations one step further and held that states should prohibit "distinction of any kind" in order to be in compliance with the principle of self-determination (UN GA Vienna Declaration article 2). Thus, the developing theory of internal self-determination applies to all groups, as a collective right, who have distinctions of any kind. Throughout this study, the subjects of the right to internal self-determination will therefore be groups of any distinction. 
Groups having distinction of any kind can be given a number of options to enjoy their internal self-determination. To comply with this obligation, governments may have some particular policies to enable groups to enjoy their economic, social and cultural rights. The fundamental step for doing this can be constitutional arrangements to protect the interests of groups (Germanakou 2007, p. 18). Thus, groups can enjoy their distinctions. They can, for example, profess and practise their religions, use their languages, establish associations and participate in public affairs (Cardenas and Canas 2002, p. 114). The extreme method for granting internal self-determination is autonomy. Groups can be given an opportunity to exercise autonomy. This type of internal selfdetermination can be seen as very extreme. However, it should be remembered that internal self-determination "require a substantial reordering of a state's domestic law in order to achieve compliance" (Fox 1995, p. 734). Thus, internal self-determination does not always require autonomy, but initially requires substantial changes in domestic affairs.

It should be pointed out here that internal self-determination is a developing right. However, its conceptual framework has been identified. Especially, the human rights approach makes this right more particular and concrete. The right at stake is closely related to economic, social and cultural human rights. However, as it is a collective right, it concerns the interests of the groups belonging to a particular territory, not to individuals within those groups. The development of the concept of internal selfdetermination cannot give a mandate to terminate external self-determination wholly. In extreme circumstances, internal self-determination can give way to external selfdetermination.

\section{II.3. The Relationship between Internal and External Self-Determination Rights}

As was discussed above, the UN very clearly stated in the 1970 Friendly Relations Declaration that it does not promote groups to "dismember or impair, totally or in part". This expression is in compliance with the principles of territorial integrity and sovereignty. Martti Koskenniemi propounded the view that the relationship between self-determination and territorial integrity is two-fold. On the one hand, internal selfdetermination seems to honour de facto existing boundaries by respecting the principle of territorial integrity (Koskenniemi 1994, p. 248). On the other hand, this situation can be overruled as a result of a denial of human rights (ibid). In other words, under international law, large-scale and repeated human rights violations might create a legitimacy to apply external self-determination (Buchanan 2004, p. 364). It should be emphasized that each denial of fundamental human rights does not directly pave the way for a right to external self-determination. In addition to this, these violations should be "gross breaches of fundamental human rights" (for example genocide, war crimes or crimes against humanity) and also there should be no possibility of a peaceful solution within borders (Cassese 1995, p. 120). 
On this point, Christine Bell (2008, p. 37) raised a crucial issue. According to Bell, all the groups in a society might have a secessionist tendency and might claim that their government does not pay attention to their human rights. This could trigger the "threat of territorial changes and disruption of the existing order" (Germanakou 2007, p. 21). In other words, external self-determination can complicate matters more when the borders of existing states are being reshaped. It can disrupt peace and security, which are the basic goals of the UN. Under its own Charter (article 1), one of the purposes of the UN is to maintain international peace and security. Thus, it can be inferred that the UN has reasonable grounds for favouring the internal aspect of the right to selfdetermination rather than the external one. This is because as a response to every gross violation of human rights, the application of external self-determination can create an insecure and unstable world. As is emphasized in Agenda for Peace (para 17), if every group claims statehood, peace and security would be more difficult goals. As internal self-determination is related to the relations within a state (Summer 2013, p. 235), it leads towards maintaining the international order, which external self-determination does not.

This tendency of the UN is also clear in UN practice. In the GA resolutions or other legal sources, the UN has always supported internal self-determination. It has never challenged the view that those groups in a society which have a distinction of any kind are entitled to the right to internal self-determination (Cassese 1995, p. 107). Furthermore, even the extreme form of internal self-determination, autonomy, has been supported by the UN for some groups (ibid). In parallel with that, there are clear resolutions that illustrate the denial by UN bodies of external self-determination claims (See UN SCR 169). ${ }^{9}$

It is worth mentioning here the relationship between UN SC and the right to internal self-determination. Since the right to internal self-determination is protected under the UN Charter, the UN SC resolutions cannot override this right. The SC itself also on occasions affirmed that its power is limited by fundamental human rights and humanitarian law norms. (See UN SCR 1456). In practice, however, deciding on whether any intervention is based on the right to internal self-determination seems more difficult. For instance, in case of Somalia, the reason for the operation was to 'ensure delivery of humanitarian assistance in Somalia'. (See UN SCR 794, Preamble). Can this aim be considered in the framework of internal self-determination? In other words, can humanitarian assistance be regarded as providing help to the Somalian peoples to enable them to use their right to internal self-determination? These are the questions which are beyond this paper's scope but worth asking.

It can also be asserted that the internal aspect of the right to self-determination has gained support from states. Since the external layer can cause boundary shifts, and thus legitimacy issues, states do not want to complicate matters by favouring external self-determination (Saul 2011b, p. 619). There is an overwhelming agreement

\footnotetext{
${ }^{9}$ For example, UN SCR 169 denies the right to external self-determination of the Congo and instead promotes territorial integrity and the political independence of the Republic of the Congo.
} 
corroborating the idea that the development of internal self-determination might be increasingly supported by states. It seems that internal self-determination complies with the principles of territorial integrity and sovereignty, unlike external self-determination. Both of these principles are historically compatible with the interests of states. As the main contributors to the development of international law are still, to a large extent, states, they may be willing to support the development of internal self-determination (Fox 1995, p. 736).

It can therefore be concluded that internal self-determination has obtained strong support from both the UN and states. However, as discussed above, development of the theory of internal self-determination does not exclude or isolate external selfdetermination. Instead, whilst the right to internal self-determination is the first resort, gross violation of it might pave the way for external self-determination. That is why it seems more appropriate to refer to them as different layers of the same right.

The relationship between the two layers might be made more concrete by a discussion of the case of Canada. The relationship between the internal and external aspects can be construed in the Supreme Court of Canada's (the Supreme Court) decision on Quebec: Reference re Secession of Quebec. One of the most significant contributions of this decision is that the Supreme Court recognised the internal aspect of the right to self-determination very clearly (Reference re Secession of Quebec para. 124). Thus, the Supreme Court recognised the Quebecers as a distinct group within the borders of Canada. Equally important, internal self-determination was claimed as a precondition for external self-determination. The Supreme Court held that it was a fact that the Quebecers had not been denied access to government. As a result of statistical analysis, the Supreme Court came to a conclusion that residents of the province could manage to pursue their economic, social and cultural rights across Canada (ibid para. 136). More importantly, they were equitably represented in legislative, executive and judicial institutions (ibid).

This decision has three crucial implications. First, it was in compliance with the argument of the present study that internal self-determination can be achieved through the enjoyment of human rights. In other words, enjoyment of human rights makes it easier to enjoy internal self-determination since it is related to economic, social and cultural rights. Second, it was in compliance with the argument of this section that external self-determination is the last resort. As long as the beneficiaries do not apply to exhaust the internal self-determination, the external aspect seems hard to be granted.

Third, the Supreme Court not only took into account the rights of individuals, it also paid attention to group rights. As was discussed above, the beneficiaries of the right to internal self-determination are groups. The Supreme Court correctly considered the extent to which the Quebecers as a group were represented in the different mechanisms of the state. Since the Quebecers were represented in the legislative, administrative and judicial bodies of Canada, their right to internal self-determination had been fulfilled. That is why the Supreme Court concluded that only when the internal 
self-determination right of the group is denied would this group be entitled to a right to external self-determination.

\section{InTERnAl Self-Determination in a PeAcebuilding ConteXt: LOCAL OWNERSHIP?}

\section{III.1. The Scope of Peacebuilding Operations and its Growing Relationship with the Concept of Internal Self-Determination}

The term 'peacebuilding' appeared in the official lexicon in 1992 under enthusiastic feelings about the end of the Cold War, although its conceptual framework can be found in previous peace studies (Chetail 2009, p. 2). The UN Secretary General (the SG) classified four activities for conflict management in his 1992 Agenda for Peace report: preventive diplomacy, peacemaking, peacekeeping and peacebuilding. The last one is the main concern of this study. The concept of peacebuilding is defined in Agenda for Peace (para. 21) as an "action to identify and support structures which will tend to strengthen and solidify peace in order to avoid a relapse into conflict". Moreover, the aims of the concept were defined as "rebuilding the institutions and infrastructures of nations torn by civil war and strife; and building bonds of peaceful mutual benefit among nations formerly at war" (ibid para. 15). Equally important, the main purpose of a peacebuilding process is summarized in the report as the "contribution of economic and social development" (ibid para. 56).

It can be clearly seen that the Agenda for Peace was a very important step since it defined the framework of the concept of peacebuilding to a certain extent. First, according to the report, the aim of the concept is to avoid any recurrence of a conflict. This implies that this aim might require the use of comprehensive means. Moreover, peacebuilding aims to (re)create an infrastructure that enables all groups to enjoy their economic and social rights. That is to say, economic and social developments seem the final goals of a peacebuilding operation. For a sustainable peace, the report focused on long-term goals, rather than on simply ending the conflict. Ending the existing conflict can be the goals of peacemaking and peacekeeping operations, but peacebuilding operations seem to lie beyond this goal. Whereas peacekeeping purposes security, peacebuilding is related to the reform process after security has been provided (Hazen 2007, p. 330). In this sense, these four conflict-management operations can be seen as having a linear relationship (Chetail 2009, p. 2). At the end of this linear system, peacebuilding operations can occur, and these operations promote economic and social development and a full recovery for a post-conflict society.

The development of the concept of peacebuilding strengthened the view that peacebuilding has long-term goals. In the Report of the Panel on UN Peace Operations (the Brahimi Report) (para. 13) peacebuilding was defined as reorganizing "the foundations of peace", thus "more than just the absence of war". The Brahimi Report has a particular importance since it expanded the mandate of the UN on intra-state conflicts and set up strategic directions for a peacebuilding operation (Lund 2003, p. 2). 
For example, in the Brahimi Report (paras 13 and 47), inter alia, respect for human rights, assistance for development and the reconciliation of the society as a whole were stated as the goals of peacebuilding. It can therefore be concluded that rather than only peace, sustainable and long-lasting peace is the target of current UN peace operations.

It should be pointed out that since the end of the Cold War, there has been a clear expansion in the mandates of peace forces (Hazen 2007, p. 327). Thus, the degree of UN involvement has increased (Rubin 2008, p. 25-26) and some new tasks have been granted to peacekeepers, such as facilitating humanitarian assistance, monitoring human rights, promoting good governance and assisting institutional reforms. This expansion of mandates creates confusion about when peacekeeping stops and peacebuilding begins. This is because there should be a starting and ending point for peacekeeping operations. As has been discussed above, the Agenda for Peace requires a linear relationship between the four conflict management operations. That is to say, although the break point between the last two of these operations is not clear in theory, this gap needs to be filled. The reason is that the actors of peacekeeping and of peacebuilding operations are completely different. The UN should start sharing the tasks with the local population when the peacebuilding process begins.

Whilst peacekeepers can be external, the success of a peacebuilding operation depends on the population which caused the conflict (ibid). It should be emphasized that the literature on peacebuilding operations is not sufficient and not clear enough. In other words, there are still gaps in how to conduct the process. However, it is clear that the actors should be the local peoples, and that the process should allow them to (re)shape their own society (White 2009, p. 219). Any intervention from outside, in contrast to peacekeeping operations, can create detrimental consequences (Daoudy 2009, p. 354). Since the end of the conflict is a necessity for the beginning of a peacebuilding operation, 'broad' UN intervention loses its legitimacy. Local peoples should be peacebuilding actors in addition to the UN for the legitimacy of the peace operations.

These goals of peacebuilding operations are definitely in compliance with internal self-determination goals. As has been discussed above, internal selfdetermination obliges states to enable all groups in a society to take part in political affairs and enjoy their economic, social and cultural rights. This means that all groups without any distinction should enjoy the right to 'have a say' under this right, and that they should be 'taken seriously' by states. Each ethnically, religious, culturally and any distinct groups should be free to choose their political status and the form of their government. They should be granted an opportunity to participate in the state's economic, social and political systems (Saul 2011a, p. 179).

According to Michael Doyle (2002, p. 97), internal self-determination has a potential to settle the causes of conflict and to create a more powerful post-conflict management system. Although this argument is completely in compliance with the argument of this study, it should be emphasized that there is no a clear jus post bellum. That is to say, there is no a clear law to apply to a post-conflict country. That is why caution should be exercised when describing the content of law to apply during a 
peacebuilding operation. However, it seems unproblematic to suggest that internal selfdetermination presents an appropriate rule of law to apply to a post-conflict country. Because it respects the political and economic decisions and interests of the groups at stake, it can make a peace process more legitimate and sustainable.

The overlapping goals of the two concepts might enable the suggestion to be made that internal self-determination is an appropriate rule of law to apply during peacebuilding operations. By respecting the right to internal self-determination of the groups in a post-conflict country, the peace process might be both legitimate and sustainable. Indeed, by improving the term 'local ownership', the UN illustrated its respect for local actors during peace processes. However, the UN is implementing this term as a policy guideline. In the next section, it will be claimed that local ownership is beyond policy guidelines; it has its roots in the right to internal self-determination.

\section{III.2. Local Ownership as a Legal Obligation for the UN: The Application of Internal Self-Determination to the Peacebuilding Context}

Regarding the source of the concept, little or no research has been carried out. It has been claimed by some scholars that local ownership takes its legitimacy from sovereignty, (Sending 2010, p. 1) or from state consent (von Billerbeck 2011, p. 352). However, both of these concepts make the source of local ownership more ambiguous rather than clarifying it. It will be claimed in this section that internal self-determination underlies the concept of local ownership. That is why the concept will be reinterpreted in the sense of internal self-determination. Since local ownership has its roots in this right, it will be asserted that the UN should consider local ownership not only as a guideline, but also as a legal obligation.

Local ownership owes its recognition to the UN. The UN interpreted this concept within a peacebuilding context. The concept was approved by the UN SG in 2001 ('No Exit without Strategy' para. 12) in the context of peacebuilding. In his report, the SG opined that the sustainability of a peace can only be achieved by the local population. In this process, the UN can only assist the local population "to develop legitimate and broad-based institutions" (ibid para. 10). In subsequent reports, the UN took this argument one step further and held that "every effort" should be in compliance with promoting local ownership in a peace operation (UN DPKO United Nations Peacekeeping Operations 2008, p. 39). The same discourse can be found in a number of Department of Peacekeeping Operations (the DPKO) guidelines, best practices, and lessons learnt documents (von Billerbeck 2011, p. 323). Thus, it seems clear that the UN has a strong commitment to local ownership. However, there are still ambiguities about the extent to which the local population will be involved in peace process.

The literature also shows no consensus on the degree of involvement of local actors. Oscar Mateos stated that the local can participate, and can be consulted in peacebuilding operation (Mateos 2011, p. 6). This seems a restrictive interpretation of local involvement in a peacebuilding process. Hannah Reich (2006, p. 15) took this 
analysis one step further and argued that local ownership should mean more than simply a participatory or consultative role given to the local. She claimed that local actors should hold "final decisive power". (ibid) Along similar lines, Necla Tschirgi (2004, p. 9) argued that the local population of a post-conflict country must manage the reconstruction process. On these grounds, it can be asserted that even though there is consensus on the involvement of local actors in the process, the extent of this involvement is not clear. That is to say, a bottom-up approach is supported by the literature. However, the question is the extent to which the bottom-up approach should be interrelated with the top-down approach. Rather than taking a side in the discussion above, it seems that in fact the issue is a result of the ambiguity of the division of tasks between external and local actors.

The division of tasks has a particular importance since it can give an opportunity for clarifying the extent of the participation of the local actors in a peacebuilding operation. Similarly, Reich's views (2006, p. 24) are grounded on the suggestion that external actors should be clear about their roles. Provided that the role and duties of external actors are clarified, this also will clarify the duties of local actors. Thus, by resolving the extent of the involvement of both sides, defining the boundaries can make a peace process more transparent and legitimate.

This issue has also been considered by the UN. In one of the recent reports of the SG, the tasks of the UN during a peacebuilding operation have been clarified to some extent. According to this report, the UN has a duty to assess national needs and capacities (UN Report of SG, 'The Rule of Law and Transitional Justice in Conflict and Post-Conflict Societies 2011, para. 14). Therefore, it should assess, inter alia, "rule of law implications of peace agreements", "the nature of the country's legal system" and "the will of the parties". (ibid) Thus, it can be claimed that the tasks of the UN are based on the assessment of how the legal system and order in the post-conflict country are being achieved. After this assessment, the UN also has to facilitate transitional justice mechanisms, by, inter alia, "training national justice officials" and "supporting judicial reform bodies". (ibid para. 12) From the wording of the report, it can be inferred that rather than a total interventionist role, the UN prefers to assess the rule of law in the country at stake and facilitate law and order if and when the country needs it. The UN's attitude illustrates that there is a consensus on the view that the main actors of a peacebuilding process are the local population concerned. The duties of the UN are also formed according to this understanding.

The issue of local actors has been a controversial and much disputed subject within the field of local ownership. It has been an issue to consider whether local ownership should be managed by the population as a whole or by the actors of the states (who will be termed 'elites'). This difference is of vital importance since different 'locals' may have very different goals and priorities in a peacebuilding process (Wong 2013, p. 48). These goals can conflict with the aim of a peace process and this might influence both the sustainability and the legitimacy of a peacebuilding operation. Although it is not easy for the UN to identify 'the locals', the processes should be inclusive as much as possible for both the legitimacy and the sustainability of the 
process. Within the scope of this paper it can be held that the local actors should include all groups having different interests in a society, including professional associations, private sector organisations, religious groups, women's organisations and human rights bodies (Nathan 2007, p. 26). Briefly, all interest groups organised autonomously are the local actors from the perspective of internal self-determination (Bell 2008, p. 212).

In some SG Reports, national ownership is promoted to increase the legitimacy of the operation (See UN Report of the SG, 'Securing States and Societies: Strengthening the United Nations Comprehensive Support to Security Sector Reform' 2013, para. 21) whilst others use national and local ownership concepts together (Agenda for Peace, para. 21). National ownership is seen in the literature as a symbol of a top-down approach since it suggests the elites as counterparts for the UN as an alternative to groups (Donais and Machold 2011, p. 5). The usage of the two terms in UN documents can be considered inconsistent. From this, it can be concluded that the UN has no clear understanding of what constitutes 'local'. Although the concept is promoted frequently, it is not explicit about to whom the ownership belongs.

In the literature too there has been an inconclusive debate about the identity of local actors. A minimalist perspective suggests that the local actors who are believed to be capable of leading the process are elites (Donais 2008, p. 9). On the other hand, a maximalist argument approves a broader local consensus. (ibid) Some scholars even take this claim further and suggest that the local actors who matter are the entire citizenry (Martin and Wilson 2008, p. 85). In the present author's opinion, neither argument is of crucial importance since neither of them depends on any legal basis, and therefore they leave space for arbitrary decisions regarding the participation of locals. That is to say, since local ownership is seen as only a policy or guideline, the UN seems not to be obliged to act under the minimalist or the maximalist perspective. What really matters is relying upon a legal basis when deciding on the local owners.

In parallel with the purpose of this study, under the human rights approach it can be asserted that the local actors should be all groups of any distinction in a post-conflict country. Under the political aspect of internal self-determination, they should be allowed to choose their own political status and the form of their government (McCorquodale 1994, p. 864). Moreover, they should have an opportunity to take part in public affairs and have access to public services, or their representatives should participate in elections as candidates.

Under the economic aspect of internal self-determination, similarly, all groups of any distinction should 'freely dispose' their natural wealth and resources. Moreover, states should take positive steps to enable all groups to have a greater enjoyment of natural wealth and resources (the SERAC case). Thus, the local actors should be all groups in the post-conflict country concerned and they should (re)shape their country by enjoying their right to political and economic self-determination. Rather than collaborating with only elites, the approach should be inclusive and bottom-up. 
Local ownership and the identification of local actors should be reinterpreted from the viewpoint of internal self-determination. Thus, all distinct groups in a postconflict country should be part of the reconstruction process. Equally important, this inclusive step should not be implemented as a policy or guideline. It should be concurred with because of its legal obligatory status. Provided that it is practised because it is a legal obligation, arbitrary decisions on the involvement of local owners can end. More legitimate and consistent practices can occur. Although local ownership is a legal obligation since it is based on the right to internal self-determination from the standpoint of this paper, in reality it is not without challenges.

\section{III.3. Local Ownership as a Hard Task for the UN: the Challenges of Application with relation to the Identification of Local Actors}

The literature shows no consensus on whether local ownership gives legitimacy and sustainability to a peace process. Whilst some scholars argue that it makes the process legitimate and sustainable, others claim the exact opposite. The latter assert that the involvement of a broad proportion of a population can create legitimate but unstable circumstances. On the one hand, Timothy Donais, who is prominent in the literature on local ownership, has claimed that the involvement of national elites could create positive consequences if they were responsive to the popular will (Donais 2008). However, in many cases, in a post-conflict country, political or military elites may not represent the whole population. (ibid) Thus, it can be claimed that the interests of these elites can be totally different from the locals' interests and will.

On the other hand, some problems with relation to the circumstances of a postconflict country may require restricting the counterparts to political and/or military elites. One of the most important issues is the capacity of the locals. It has been argued that the peacebuilding process demands a capacity for making reforms and transitioning to a peace society. However, in post-conflict circumstances only political and military elites may have capacity to realize such reforms. Exclusion of these elites would result in and justify ‘a more hands-on approach’ by external actors (Mateos 2011, p. 7).

To portray the issue in Sarah von Billerbeck's terms (2011, p. 339), local ownership complicates the building of peace in a country. She argued that the multiplicity of local owners makes it difficult to have a consensus of all the population. (ibid) According to her, the UN should 'choose' its counterparts from the elites. (ibid p. 342) This would increase the UN's ability to obtain positive results more quickly. (ibid 343) von Billerbeck drew attention to very significant points with reasonable arguments. However, first, for an external body (that is, the UN), the process of 'choosing' partners does not seem to be without problems. To 'choose' may mean to decide the 'winners' of the conflict, empowering some actors and disempowering others (Stromseth, Whippman and Brooks 2006, p. 379). Unavoidably, there may appear a perception on the part of the entire population that those who are chosen to be a partner of the UN are the winners of the conflict. This can damage the peacebuilding process. Second, preferring the elites in order to achieve rapid and positive results is reminiscent 
of Annika S. Hansen's famous 'elite capture' term. In accordance with this term, external actors talk only to the top levels of government and other elites (Hansen 2008, p. 45). As a result of this practice, external actors inevitably trade legitimacy for the sustainability of the peace process.

Even if this trade off and elite capture were avoidable to a certain extent, it is not what internal self-determination requires. From the perspective of internal selfdetermination, in a post-conflict country, all groups have a right to both political and economic internal self-determination. In the reconstruction period, all groups should take part in public affairs and have a right to approve or contest the reforms at stake. They should enjoy a right to choose their own political status and the form of the government. Under economic self-determination, all the groups in the country should share equally all natural wealth and resources. Furthermore, they should 'freely dispose' the resources without any oppression. Here, it should be emphasized that local ownership does not exclude externals as a whole (Chesterman 2007, p. 21). Conversely, it welcomes any external involvement as long as it stimulates local interests (Nathan 2008, p. 21). That is to say, any step from externals which encourages local owners to enjoy their political and economic internal self-determination rights is welcome.

The rationale of the argument of the study is the fact that the reconstruction process is an extremely large and tense process, so the presence of an explicit opposition on the part of the locals makes it harder to accomplish the tasks of the peace process (Donais 2012, p. 12). This can be because of, first, the practical reasons. To implement reforms and peace agreements, the participation and mutual cooperation of all parts of the population is necessary. Second, as has been discussed above, after the peacekeeping phase is over, the peacebuilding process should be driven by local actors since the legitimacy of the intervention ceases when the conflict ends.

Third, recent cases show that the sustainability of a peacebuilding operation does not depend only on the consent and approval of the political and military elites. In a post-conflict country, locals can block or undermine even the most carefully designed policy reforms (Donais 2009, p. 125). Thus, it can be held that all groups in a postconflict country whose interests are not satisfied might have a capacity to undermine the sustainability of the peace process. That is why all groups' interests should be represented and protected in a peace process.

On the other hand, it cannot be claimed that locals are the best counterparts for the UN. As happened in Sierra Leone between 2002 and 2007, the local can be too weak to be counterparts. (Wong 2013, p. 48) Or, as happened in Afghanistan, the involvement of locals can totally destroy law and order. (ibid p. 50) So it cannot be claimed that local actors always create the best results. However, despite all the challenges, the main argument is that a peace process which respects and encourages the locals to enjoy their internal self-determination right tends to be sustainable and legitimate. In other words, a local-involving peace process is more likely to create good results in the long-term (Reno 2008, p. 154) such as in Colombia (see Bell 2013). 
The Right to Internal Self-Determination in Peacebuilding Processes:

A REINTERPRETATION OF THE CONCEPT OF LOCAL OWNERSHIP FROM A LEGAL PERSPECTIVE

\section{THE CASE OF THE CONGO: EXCLUSION OF LOCAL OWNERSHIP FROM THE Peacebuilding Process}

\section{IV.1. A story of failure: Where is Local in the Congo Peace Process?}

Here, the analysis above will be discussed in the context of the case of the Congo. The period is defined by the two Congo wars and the UN Organization Mission in the Democratic Republic of the Congo (MONUC). The Congo case is a representative case because, first, it clearly shows the exclusion of the locals from the peace process. Second and more important, this exclusion of the locals undermined the top-down approach and precluded peace. Therefore, this case clearly illustrates the significance of local ownership. Third, the neglect of the locals cannot be based on a lack of capacity, or the reluctance of locals, or anything else in the Congo case, other than arbitrary decisions by the peacebuilders. Thus, it will be argued that the ignorance of the local was intentional and, in Séverine Autesserre's words, was part of the UN's "peacebuilding culture” (2010, p. 10).

The study concerns the period starting from the First Congo War (1996-97). The exclusion of local actors from the peace negotiations following the First and Second Congo Wars will be analysed first. Second, the process by which the local actors undermined the peace process will be described. The intention is to conclude that for a legitimate and sustainable peace, local ownership is a sine qua non. All groups in a post-conflict country should be 'taken seriously' and their right to internal selfdetermination should be respected.

The First Congo War started in 1996 and occurred between at least nine African states. Neighbour states of the Congo (then Zaire) pursued a goal to replace President Mobutu Sésé Seko with Laurent Kabila and invaded the Congo. After negotiations, Mobutu left the country and the invader neighbours withdrew. A negotiation for peace started. Here it is necessary to emphasize that the negotiation process did not involve the Congolese local actors, non-governmental organisations, opposition leaders and so on. However, the war also had local dynamics and local-level causes. Since the talks in the negotiation process did not address them, the conflicts were not appeased as a whole.

The Second Congo War broke out as a result of the same reasons. The former supporters of Kabila now wanted him to give up the presidency. This time, the neighbour states were not 'successful'. Kabila stayed in post. At the end of the war, a ceasefire agreement was drafted by the UN and the Organisation of African Unity (the OAU). Despite all the challenges and strife, the Lusaka Ceasefire Agreement (the Lusaka) was signed in 1999. After the assassination of Kabila, his son Joseph became president in 2001. In 2006, elections were held in the country and Joseph Kabila this time became the first democratically elected president of the country. After this democratic step, the international community hoped that finally the Congo would have a sustainable peace (Autesserre 2008). However, all the peace agreements and elections 
did not bring peace to the Congo. This was because the conflict had also local dynamics which were not addressed during the negotiations and in the peace agreement.

Since the end of colonization, there had been a struggle for land among the Congolese (Autesserre 2008, p. 130). These conflicts over land created deep-rooted antagonisms between different groups long before wars of the 1990s (ibid p. 133). These local conflicts escalated the violence during the two wars (ibid p. 142). However, the land was not the only issue. The natural resources and local tax payment issues were also significant problems. As a researcher who worked on the Congo peacebuilding for a long period, Séverine Autesserre claimed that the local conflicts had been often autonomous from regional and national conflicts (ibid p. 178). Therefore, reasons such as local-level political power issues, national wealth and resources, and social status resulted in battles which could not be ended by a top-down approach (ibid). In other words, regional and national actors and their top-down peacebuilding efforts fell short of addressing the root causes of the conflict.

The peace negotiations in the Congo case illustrate the fact that international actors tried to find the reasons of the conflict only at the regional or national levels. Since only top level issues were taken into consideration, the peace negotiations only included the political and military elites of the Congo. To be more precise, during the Lusaka negotiations, at the table only the two main armed groups, the government of the Congo and representatives of five neighbouring states were sitting (Hellmüller 2011, p. 8). International Crisis Group asserted that this situation did not offer any choice for unarmed actors to have any input for either their future or their country's future (ICG Report 1999, p. 4). Although a 45-day-long national dialogue and reconciliation process was stipulated for the Lusaka negotiations (Lusaka Ceasefire Agreement 1999, chapter 5), this process was never implemented by the government (Carayannis 2009, p. 10).

To conclude, the locals were continually excluded from the peace process in the Congo case. Although the conflict had regional, national and local level causes such as land, tax payments and the distribution of natural resources, local issues were not addressed during the peace process. This resulted in the recurrence of the conflict. This exclusion of local actors is not a situation that can be attributed to the circumstances of the case. It has deep-rooted causes: the 'peacebuilding culture' of the UN.

\section{IV.2. Ignorance of Local Actors as a Violation of Internal Self- Determination: Is this a UN 'Peacebuilding Culture'?}

In the Congo case, it has been seen that neglect of the local is a part of, in Autesserre's term, “the UN peacebuilding culture” (Autesserre 2010, p. 10). Since the participation of locals, in other words local ownership, is not attributed to any legal norm, local actors are constantly ignored in peace processes. This may create a conflict of priorities between local actors and externals. Worse, the Congo case demonstrates that the application of local ownership can be at times arbitrary, and the involvement of 
local groups can depend on the decisions of the peacebuilders in question. In order to prevent this inconsistency and arbitrariness, the UN needs to reinterpret local ownership by grounding it in the right of local actors to internal self-determination.

In the period with which this study is concerned, the Congo hosted the MONUC. Following the signing of the Lusaka agreement, the MONUC was sent to the Congo to supervise the implementation of the cease-fire agreement in November 1999 (Eriksen 2009, p. 657). It was mandated by Security Council Resolution 1279 (para. 2) which encouraged all the Congolese to participate in the national dialogue and reconciliation process mentioned above. This can be interpreted as a mandate to promote local involvement in the peacebuilding process. However, the practice shows that the mandate was implemented arbitrarily. This claim will be analysed through an example.

As a Deputy Special Representative of the UN SG, Lena Sundh initiated a project in the Congo which included local groups into the peace process in 2003 (Autesserre 2010, p. 193). Under Sundh, it was asserted that the conflict had local, provincial and regional dynamics. Thus, her team regretted that the peace process was involving only state actors (elites) and the UN, even though the conflict had many other actors on different levels (ibid). There were attempts to resolve local tensions over the land and natural wealth and resources by the involvement of locals under the leadership of Sundh (ibid p. 196). However, when Sundh's team left the mission, the bottom-up approach again was replaced by the top-down approach. Therefore, the land and natural resources issues had not been addressed.

How the peacebuilding method of the UN depends on the peacebuilders at stake can also be observed in the SG reports on the MONUC. When Sundh was in post, the reports paid attention to local conflict resolution efforts. In these reports the SG was reporting the benefits of these efforts (UN Fourteenth Report of the SG on the MONUC, paras 13 and 14). It was reported that local-level initiatives were effective in the reduction of the conflict at the provincial level (ibid para 13). However, immediately after Sundh's team had left, the subsequent report did not even mention the lack of these efforts (UN Fifteenth Report of the SG on the MONUC). It seems that local initiatives were rapidly neglected or forgotten.

This case illustrates that local ownership is seen by the UN just as a policy which can be implemented to different extents depending on the decision of the peacebuilders. This creates inconsistency, as is shown in the Congo case. While the MONUC did take into consideration the bottom-up approach in 2003, in the following year this approach was replaced with the top-down one. This caused the neglect of local groups' priorities. Worse, this can result in a conflict of priorities and interests between locals and externals.

In the Congo, the local population were unable to enjoy their right to internal self-determination from both the political and the economic aspects. As long as the locals were denied any opportunity to take part in domestic affairs, they also could not benefit from the Congo's natural wealth and resources. The reason for this was the 
difference in priorities. Instead of promoting and facilitating these rights, the MONUC focused on the elections. However, it can be seen in the Congo case that elections are not the solution for sustainable peace. On the contrary, elections can re-create clashes in a post-conflict society.

There is no clear evidence showing whether elections in a post-conflict country can decrease the risk of conflict (Ndulo and Lulo 2010, p. 156). This is because elections do not address structural problems such as the unequal distribution of natural wealth and resources (Autesserre 2010, p. 240). A top-down approach envisions a process of elections as soon as possible. From the perspective of externals, an election is an indicator of a successful peacebuilding operation since it has the potential to create a capable state (Ndulo and Lulo 2010, p. 169). A top-down approach finds all the reasons of the conflict between regional and national dynamics as happened in the Congo. That is why under this approach it is asserted that since all conflicts are the consequences of tensions between these actors, an election would solve all the issues (Autesserre 2010, p. 245). However, immediately after the 2006 Congo elections, the violence escalated again. Especially so in some provinces of the Congo where there was a return to all-out war (ibid p. 246). Therefore, it seems clear that local conflicts can be capable of undermining top-down attempts to reinforce the peace without addressing the root causes (Sisk and Risley 2005, p. 5).

It is a fact that the UN could not manage to accommodate a bottom-up approach in the Congo. It was simply not sensitive to the local context. Along similar lines, one scholar has argued that the reason for this insensitivity is that UN privileges the universal moral over the local (Sending 2009, p. 4). The privileging of the elections in the Congo can be considered in this sense. Rather than addressing the root causes of the conflict such as distribution of land and other natural resources in the context of the Congo, the UN attempted to legitimize its intervention by applying universal values (Huggins 2010, p. 35). That it was not interested in local problems is demonstrated by its assessing the success of the operation over universal values (such as democratic society). However, the application of these values before solving the basic issues did create negative consequences.

Peace builders should promote internal self-determination. This right has a capability to solve the root causes of the conflict. For instance, economic selfdetermination could solve the land and natural wealth issues. As was pointed out by the GA, the conflict in the Congo was a result of the natural resources (namely, diamonds) issue (UN GA Res 55/56, Preamble). According to the resolution, there was a link between conflict diamonds and armed conflict (ibid para. 2). Moreover, it was clarified by the SG that the areas involved in the conflict were the very areas in which the exploitation of natural resources was the most widespread. That is why the escalation of the conflict could have been stopped by respecting and facilitating the right to economic self-determination. As discussed above, the enjoyment of economic self-determination could have enabled the Congolese to enjoy their other human rights as well. 


\section{CONCLUSiON}

This paper has addressed the gap related to the source of local ownership and put forward the view that the right to internal self-determination may be claimed as the source of the concept of local ownership. The right to internal self-determination of the local actors in a post-conflict country makes the concept a legal obligation for the UN. Thus, this study has been an attempt to re-explore or re-interpret the concept of local ownership from a legal standpoint.

The significant consequence of this reinterpretation has been the identification and clarification of local actors. Both UN documents and the literature on local ownership show no consensus on the identity of local actors. Whilst some scholars support political and military elites under the approach of national ownership, others claim that ownership should be more local-inclusive and bottom-up. Both views have benefits and costs. The former view, which has also been supported by the UN to some extent, supports the partnership of the elites since involvement of more actors can undermine a consensus and complicate the peace process. The latter view, however, claims that for a legitimate peace process, the voices of all different interest groups should be heard. Therefore, it seems that peacebuilders are supposed to choose either sustainability or legitimacy, but not both. This is because from these two different perspectives, the realization of both sustainability and legitimacy at the same time seems difficult.

This article has sought to address this issue by identifying the local actors from a legal perspective. It defends the view that what really matters is relying on a legal ground when deciding on the local owners to create consistency between peacebuilding operations. The holders of the right to internal self-determination have been advocated as the actors with whom the UN is obliged to manage a peacebuilding operation. For this reason, the nature of the right to internal self-determination has been identified and the development of the right to self-determination has been traced using a human rights approach. The holders of the right to internal self-determination have been found to be 'groups of any distinction'. Since internal self-determination is a collective right, it aims to protect groups which have any distinction in a society.

The study puts forward the view that the UN is under an obligation to collaborate with these groups in a post-conflict society. In other words, all groups in a society having distinction of any kind, such as race, creed, gender, religion, language and so on, should be counterparts of the UN in peacebuilding processes from the perspective of internal self-determination. These groups should have a right to take part in the public affairs of their country and should be represented in the legislative, executive and judicial bodies of the state concerned (political self-determination). Furthermore, they should freely dispose their natural wealth and resources without oppression, and the resources should be equally distributed for the benefit of the groups (economic self-determination). 
The significance of the actors has been illustrated and discussed in the context of the Congo case. The Congo case has confirmed that different locals have different interests and priorities in a peacebuilding process. When the UN collaborates only with political and military elites, their interests and priorities can conflict with the majority's interests and priorities. Nevertheless, some scholars have claimed that the inclusion of more actors complicates the peace process and makes it difficult to create a consensus in a post-conflict country. However, the Congo shows the exact opposite.

The Congo case has some crucial lessons for future peacebuilding operations. In the Congo, under a top-down approach, the causes of the conflict were identified as national and regional dynamics. The power struggle between these dynamics has been claimed as the main reason for the conflict(s). As a result of this, it has been defended that elections could solve the issue and put an end to all conflicts. However, the conflicts in the Congo had different levels. Top-down remedies could not create any solutions for the local-level conflicts.

The root causes of the local-level conflict in the Congo were the distribution issues of the land and other natural resources. Different groups there had always clashed with each other because of the land issues. It is also a fact that there had long been a link between natural resources and armed conflicts in the Congo as the GA Resolutions have repeatedly confirmed. However, these tensions have not been addressed and the roots of the local-level conflict has not been paid attention but have simply been disregarded.

The local ownership approach should be re-accommodated by the UN by grounding it on the right to internal self-determination. Thus, the participation of locals should be considered as a legal obligation and the identification of local actors should be revised under internal self-determination. The relationship between internal selfdetermination and peacebuilding needs to be explored by both the UN and the peacebuilding literature. The right to internal self-determination offers a legal 'checklist' for the UN to provide both legitimacy and sustainability to peacebuilding processes. The right to internal self-determination needs enforcement mechanisms to be binding and respected. The HRC should revisit its opinion over the admissibility of communications under this right. The current practice of the HRC makes this right nonjusticiable. Especially, the internal self-determination right of post-conflict societies can be recognised and crystallised with possible cases. This would also help to clarify the distribution of the tasks of externals and local actors in relation to the peacebuilding process. Clarification of the tasks is of vital importance since the ambiguity militates against the local actors and prevents them from exercising their right to internal selfdetermination. 


\section{REFERENCES}

ALSTON, Philip (ed.) (2001). Peoples’Rights. Oxford, Oxford University Press.

AUTESSERRE, Séverine (2008). The Trouble with Congo: How Local Disputes Fuel Regional Conflict. [online]. Foreign Affairs, 3 May. http://www.foreignaffairs.com/articles/63401/s Ã Cverine-autesserre/the-trouble-withcongo

AUTESSERRE, Séverine (2010). The Trouble with the Congo: Local Violence and the Failure of International Peacebuilding. Cambridge, Cambridge University Press. DOI: https://doi.org/10.1017/cbo9780511761034

BELL, Christine (2008). On the Law of Peace: Peace Agreements and the Lex Pacificatoria. Oxford, Oxford University Press.

DOI: https://doi.org/10.1093/acprof:oso/9780199226832.001.0001

BELL, Christine (2013). Women and Peace Processes, Negotiations, and Agreements: Operational Opportunities and Challenges [online]. NOREF Policy Brief. http://www.peacebuilding.no/var/ezflow_site/storage/original/application/b6f94e1df29 77a0f3e0e17dd1dd7dcc4.pdf.

BUCHANAN, Allen (2004). Justice, Legitimacy, and Self-Determination: Moral Foundations for International Law. Oxford, Oxford University Press.

CARAYANNIS, Tatiana (2009). The Challenge of Building Sustainable Peace in the DRC [online]. Centre for Humanitarian Dialogue Background Paper http://www.hdcentre.org/uploads/tx_news/69DRCpaper.pdf.

CASSESE, Antonio (1995). Self-Determination of Peoples: A Legal Reappraisal. Cambridge, Cambridge University Press.

CASTELLINO, Joshua (2000). International Law and Self-Determination: The Interplay of the Politics of Territorial Possession with Formulations of Post-colonial National Identity. London, Martinus Nijhoff Publishers.

CHESTERMAN, Simon (2007). Ownership in Theory and in Practice: Transfer of Authority in UN Statebuilding Operations. Journal of Intervention and Statebuilding 1 (1), 3-26.

DOI:https://doi.org/10.1080/17502970601075873

CHETAIL, Vincent (2009). Introduction: Post-Conflict Peacebuilding: Challenges and Ambiguities of a Concept in Search of Identity. In: CHETAIL, Vincent (ed.), PostConflict Peacebuilding: A Lexicon. Oxford, Oxford University Press 1-29.

CRAWFORD, James (2001). The Right of Self-Determination in International Law: Its Developments and Future. In: ALSTON, Philip (ed.), Peoples’ Rights. Oxford, Oxford University Press, 7-68.

DANSPECKGRUBER, Wolfgang (ed.) (2002). The Self-Determination of Peoples: Community, Nation, and State in an Interdependent World. London, Lynne Rienner Publishers. 
DAOUDY, Marwa (2009). State-building. In: CHETAIL, Vincent (ed.), Post-Conflict Peacebuilding: A Lexicon. Oxford, Oxford University Press, 350-358.

Democratic Republic of Congo Lusaka Ceasefire Agreement (10 July 1999).

DONAIS, Timothy (2008). Understanding Local Ownership in Security Sector Reform. In: DONAIS, Timothy (ed.) Local Ownership and Security Sector Reform. Geneva, LIT Verlag, 3-18.

DONAIS, Timothy (2009). Inclusion or Exclusion? Local ownership and Security Sector Reform. Studies in Social Justice 3 (1) 117-131.

DONAIS, Timothy (2012). Peacebuilding and Local Ownership: Post-conflict Consensus Building. London, Routledge.

DONAIS, T, and MACHOLD, R. (2011). From Rhetoric to Practice: Operationalizing National Ownership in Post-Conflict Peacebuilding. [online] UN Workshop Report, Ontario. http://www.un.org/en/peacebuilding/pbso/pdf/national_ownership_report.pdf.

ERIKSEN, Stein (2009). The Liberal Peace is neither: Peacebuilding, State Building and the Reproduction of Conflict in the Democratic Republic of Congo. International Peacekeeping, 16 (5), 652-666. DOI: https://doi.org/10.1080/13533310903303289

FAN, Hua (2008). The Missing Link between Self-Determination and Democracy: The Case of East Timor. Northwestern Journal of International Human Rights 6 (1) 176.

FARMER, Alice (2006). Towards a Meaningful Rebirth of Economic Self-Determination: Human Rights Realization in Resource-Rich Countries. New York University Journal of International Law and Politics, 39 (2), 417-473.

FOX, G. (1995). Self-Determination in the Post-Cold War Era: A New Internal Focus? Michigan Journal of International Law, 16 (1), 733-781.

GERMANAKOU, Vasiliki (2007). Substantiating the Right to Democratic Governance: Internal Self-Determination as a Means of Empowerment. [online]. LSE working conference.

http://www.lse.ac.uk/humanRights/archive/articlesAndTranscripts/Conference07_Ger manakou.pdf.

GREEN, Leslie (1995). Internal Minorities and their Rights. In: BAKER, J. (ed.) Group Rights. Toronto, University of Toronto Press, 257-272.

HANSEN, A. (2008). Local Ownership in Peace Operations. In: DONAIS, Timothy (ed.) Local Ownership and Security Sector Reform. London, LIT Verlag, 39-58.

HANSEN, A. and WIHARTA, S. (2007). The Transition to a Just Order - Establishing Local Ownership after Conflict: A Practitioners' Guide [online]. Folke Bernadotte Academy Publications. http://www.jus.umu.se/digitalAssets/12/12609_transition_to_order.pdf.

HAZEN, J. M. (2007). Can Peacekeepers be Peacebuilders? International Peacekeeping, 14 (3), 323-338. DOI: https://doi.org/10.1080/13533310701422901

HELMUELLER, S. (2013). Bridging the Disconnect: Integrating Local Perspectives in Peace Processes. International Peacekeeping, 20 (2), 201-234.

HUGGINS, Chris (2010). Land, Power and Identity: Roots of Violent in Eastern DRC. [online]. International Alert Report. http://www.internationalalert.org/sites/default/files/DRC_LandPowerIdentity_EN_2010.pdf. 
International Crisis Group (1999). The Agreement on a Cease-Fire in the Democratic Republic of Congo: An Analysis of the Agreement and Prospects for Peace. [online]. ICG DRC Report 5/1999.

http://www.crisisgroup.org/ /media/Files/africa/central-africa/drcongo/Democratic\%20Republic\%20of\%20Congo\%20An\%20Analysis\%20of\%20the \%20Agreement\%20and\%20Prospects\%20for\%20Peace.pdf.

Ivan Kitok v Sweden UN Human Rights Committee, Comm No 197/1985 (1988).

Katangese Peoples' Congress v Zaire African Commission on Human and Peoples' Rights, Comm No 75/92 (1995).

KLABBERS, Jan (2006). The Right to be Taken Seriously: Self-Determination in International Law. Human Rights Quarterly 28 (1), 186-206.

DOI: https://doi.org/10.1353/hrq.2006.0007

KOSKENNIEMI, Martti (1994). National Self-Determination Today: Problems of Legal Theory and Practice. International and Comparative Law Quarterly 43 (2), 241-269. DOI: https://doi.org/10.1093/iclqaj/43.2.241

KREUTER, Aaron C. (2010). Self-Determination, Sovereignty, and the Failure of States: Somaliland and the Case of Justified Secession. Minnesota Journal of International Law 19 (2), 363-397.

LUND, Michael (2003). What Kind of Peace is Being Built? Taking Stock of Post-Conflict Peacebuilding and Charting Future Directions. [online]. International Development Research Centre Paper.

http://web.idrc.ca/uploads/user-S/10527469720lund_final_mar_20.pdf.

MARTIN, A. and WILSON, P. (2008). Security Sector Evolution: Which Locals? Ownership of What? In: DONAIS, Timothy (ed.). Local Ownership and Security Sector Reform. London, LIT Verlag, 83-103.

MATEOS, Oscar (2011). Local Ownership and Liberal Peacebuilding: From Rhetoric to Practice? Sierra Leone as a Case Study. [online]. European Conference on African Studies. Academia.

https://www.academia.edu/2985649/MATEOS_O._2011_Local_Ownership_and_Liberal_Pea cebuilding_From_Rhetoric_to_Practice_Sierra_Leone_as_a_Case_Study.

McCORQUODALE, Robert (1994). Self-Determination: A Human Rights Approach. International and Comparative Law Quarterly 43 (4), 857-885.

DOI: https://doi.org/10.1093/iclqaj/43.4.857

MHANGO, M.O. (2007). Recognizing a Right to Autonomy for Ethnic Groups under the African Charter on Human and Peoples' Rights: Katangese Peoples' Congress $v$ Zaire. [online]. Human Rights Brief.

https://www.wcl.american.edu/hrbrief/14/2mhango.pdf.

Mikmaq Tribal Society v Canada UN Human Rights Committee, Comm No 78/1980 (1984).

NATHAN, Laurie (2007). No Ownership, No Commitment: A Guide to Local Ownership of Security Sector Reform. [online]. University of Birmingham publication. http://epapers.bham.ac.uk/1530/1/Nathan_-2007-_No_Ownership.pdf. 
NATHAN, Laurie (2008). The Challenge of Local Ownership of SSR: From Donor Rhetoric to Practice. In: DONAIS, Timothy (ed.), Local Ownership and Security Sector Reform. London, LIT Verlag, 19-36.

NDULO, Muna and LULO Sara (2010). Free and Fair Elections, Violence and Conflict. Harvard International Law Journal 51 (1), 155-171.

RAIC, David (2002). Statehood and the Law of Self-Determination. London, Kluwer Law International.

Reference re Secession of Quebec, [1998] 2 SCR 217.

REICH, Hannah (2006). Local Ownership in Conflict Transformation Projects: Partnership, Participation or Patronage? [online]. Berghof Occasional Paper No 27. http://reliefweb.int/sites/reliefweb.int/files/resources/CDDB393F195EC54EC125727A 005937C3-Berghof-peace\%20building-Sep2006.pdf.

RENO, W (2008). Bottom-up Statebuilding. In: CALL Charles T. and WYETH Vanessa (eds), Building States to Build Peace. London, Lynne Rienner Publishers, 143-162.

ROETHKE, Peter (2011). The Right to Secede under International Law: The Case of Somaliland. Journal of International Service 20 (2), 35-47.

ROSAS, Allan (1993). Internal Self-Determination. In TOMUSCHAT, Christian (ed), Modern Law of Self-Determination. London, Martinus Nijhoff Publishers, 225-252.

RUBIN, B.R. (2008). The Politics of Security in Postconflict State Building. In: CALL Charles T. and WYETH Vanessa (eds), Building States to Build Peace. London, Lynne Rienner Publishers, 25-48.

SAUL, Matthew (2011a). Local Ownership of Post-Conflict Reconstruction in International Law: The Initiation of International Involvement. Journal of Conflict and Security Law 16 (1), 165-206. DOI: https://doi.org/10.1093/jcsl/krq023

SAUL, Matthew (2011b). The Normative Status of Self-Determination in International Law: A Formula for Uncertainty in the Scope and Content of the Right? Human Rights Law Review 11 (4), 609-644. DOI: https://doi.org/10.1093/hrlr/ngr025

SENDING, Ole Jacob (2009). Why Peacebuilders Fail to Secure Ownership and be Sensitive to Context. [online]. Norwegian Institute of International Affairs Working Paper 755. http://mercury.ethz.ch/serviceengine/Files/ISN/103581/ipublicationdocument_singled ocument/07cfd48a-587e-4815-981e-a694467595ec/en/SIP-1-WP-755-Sending.pdf.

SENDING, Ole Jacob (2010). Learning to Build a Sustainable Peace: Ownership and Everyday Peacebuilding. [online]. Chr. Michelsen Institute Report. http://www.cmi.no/publications/file/3732-learning-to-build-a-sustainable-peace.pdf.

SISK, Timothy and RISLEY, Paul (2005). Democracy and Peacebuilding at the Local Level: Lessons Learned. [online]. Institute for Democracy and Electoral Assistance Report. http://www.idea.int/conflict/upload/DLL_Lessons_Learned.pdf.

Social and Economic Rights Action Centre (SERAC) and another $v$ Nigeria African Commission on Human and Peoples’ Rights, Comm No 155/96 (2001).

STROMSETH, Jane, WIPPMAN, David and BROOKS, Rosa (2006). Can Might Make Rights? : Building the Rule of Law after Military Interventions. Cambridge, Cambridge University Press. DOI: https://doi.org/10.1017/cbo9780511803086 
SUMMERS, James (2013). The Internal and External Aspects of Self-Determination Reconsidered. In: FRENCH, Duncan (ed). Statehood and Self-Determination: Reconciling Tradition and Modernity in International Law. Cambridge, Cambridge University Press, 229-249. DOI: https://doi.org/10.1017/CBO9781139248952.014

THIO, Li-ann (2002). Battling Balkanization: Regional Approaches toward Minority Protection beyond Europe. Harvard International Law Journal 43 (2), 409-468.

THURER, Daniel and BURRI, Thomas (2010). Self-Determination. [online]. Max Planck Encyclopaedia of Public International Law.

http://ilmc.univie.ac.at/uploads/media/self-determination_empil.pdf.

TSCHIRGI, Necla (2004). Post-Conflict Peacebuilding Revisited: Achievements, Limitations, Challenges. [online]. International Peace Academy Peacebuilding Forum Conference Paper.

http://www.un.org/esa/peacebuilding/Library/Post_Conflict_Peacebuilding_IPA.pdf.

UN DPKO ‘United Nations Peacekeeping Operations: Principles and Guidelines’ (18 January 2008).

UN Fifteenth Report of the Secretary General on the MONUC, UN Doc S/2004/251 (25 March 2004).

UN Fourteenth Report of the Secretary General on the MONUC, UN Doc S/2003/1098 (17 November 2003).

UN GA 'Declaration on the Granting of Independence to Colonial Countries and Peoples' UN Doc A/RES/1514(XV) (14 December 1960).

UN GA 'Report of the Special Committee on Principles of International Law Concerning Friendly Relations and Cooperation Among States' UN Doc A/8018 (24 October 1970).

UN GA Res 55/56, UN Doc A/RES/55/56 (29 January 2001).

UN GA 'Vienna Declaration and Programme of Action' UN Doc A/CONF.157/23 (20 December 1993).

UN Human Rights Committee, General Comment 25, UN Doc CCPR/C/21/Rev.1/Add.7 (12 July 1996).

UN Report of the Panel on UN Peace Operations UN Doc A/55/305-S/2000/809 (21 August 2000).

UN Report of the Secretary General, 'An Agenda for Peace Preventive Diplomacy, Peacemaking and Peace-keeping’ UN Doc A/47/277-S/24111 (17 June 1992).

UN Report of the Secretary General, 'No Exit without Strategy: Security Council DecisionMaking and the Closure or Transition of United Nations Peacekeeping Operations' UN Doc S/2001/394 (20 April 2001).

UN Report of the Secretary General, 'Securing States and Societies: Strengthening the United Nations Comprehensive Support to Security Sector Reform' UN Doc A/67/970S/2013/480 (13 August 2013).

UN Report of Secretary General, 'The Rule of Law and Transitional Justice in Conflict and Post-Conflict Societies’ UN Doc S/2011/634 (12 October 2011). 
UN SC Res 169, UN Doc S/RES/169 (24 November 1961).

UN SC Res 794, UN Doc S/RES/794 (3 December 1992).

UN SC Res 1456, UN Doc S/RES/1456 (20 January 2003).

van den DRIEST, Simone (2010). Pro-Democratic Intervention and the Right to Political Self-Determination: The Case of Operation Iraqi Freedom. Netherlands International Law Review 57 (1), 29-72. DOI: https://doi.org/10.1017/S0165070X10100023

von BILLERBECK, Sarah B.K. (2011). Whose Peace? Local Ownership and UN Peacebuilding. [online]. Special Issue of the Journal of Intervention and Statebuilding. http://oneearthfuture.org/sites/oneearthfuture.org/files/images/content/news/norwegian missionprogram.pdf.

WHITE, Nigel (2009). Peace Operations. In: CHETAIL, Vincent (ed). Post-Conflict Peacebuilding: A Lexicon. Oxford, Oxford University Press, 213-227.

WOLFF, Jonas (2014). The Question of Self-Determination in International Democracy Promotion. [online]. Peace Research Institute Frankfurt Working Paper No:19 https://www.files.ethz.ch/isn/184718/PRIF_WP_19.pdf .

WONG, Pearly (2013). Local Ownership in Peacebuilding: A Premature Rhetoric? United Nations University Peace and Progress 1 (1), 47-57. 